\title{
Molecular detection of rifampicin resistance in multidrug-resistant Mycobacterium tuberculosis strains from North-Eastern Romania
}

\section{Detecția moleculară a rezistenței la rifampicină pentru tulpini multidrog- rezistente de Mycobacterium tuberculosis izolate în nord-estul României}

\author{
Cătălina Luncă ${ }^{1}$, Olivia S. Dorneanu ${ }^{1,2}$, Daniela Diculencu ${ }^{3}$, Teodora Vremeră ${ }^{1,4 *}$, \\ Aida C. Bădescu ${ }^{1,2}$, Simona Peter Olaru ${ }^{3}$, Luminița S. Iancu ${ }^{1,5}$ \\ 1. "Grigore T. Popa" University of Medicine and Pharmacy Iaşi, Microbiology Department \\ 2. "St. Parascheva" Clinical Hospital of Infectious Diseases Iaşi \\ 3. Clinical Hospital of Pulmonology Iaşi \\ 4. "St. Spiridon" Clinical Emergency Hospital Iaşi \\ 5. National Institute of Public Health - Regional Center of Public Health Iaşi
}

\begin{abstract}
Introduction: Multidrug-resistant tuberculosis (MDR-TB) represents an important public health problem. Rapid molecular methods detect the mutations responsible for drug-resistance and can shorten the time required for diagnosis and initiation of appropriate therapy. The objectives of our study were to optimize a multiplex allele-specific PCR technique (MAS-PCR) to detect rpoB mutations and to specify the type and frequency of these mutations. Material and methods: We have tested 47 non-duplicate MDR-TB, including extensively drugresistant tuberculosis (XDR-TB) strains, identified during 2007-2012, using MAS-PCR for detection of mutations in rpoB codons 531, 526 and 516. Results: The most common mutation was located in codon 531 (63.82\%), while only $12.76 \%$ and $10.63 \%$ of the strains showed mutations in codon 516 and 526, respectively; for six strains we have not identified mutation in the targeted codons. Conclusion: MAS-PCR revealed the mutations prevalent in our region, with good sensitivity (87.2\%), suggesting the usefulness of this test in the rapid diagnosis of $M D R-T B$.
\end{abstract}

Keywords: $M D R-T B, M A S-P C R, R I F$ resistance, rpoB gene

\section{Rezumat}

Introducere: Tuberculoza multidrog-rezistentă $(M D R-T B)$ reprezintă o importantă problemă de sănătate publică. Metodele moleculare rapide evidențiază mutațiile responsabile de rezistența la antituberculoase, scurtând timpul necesar diagnosticului şi iniţierii tratamentului adecvat. Obiectivele studiului au fost

"Corresponding author: Teodora Vremeră: 16, Universităţii Street, Iaşi 700115, Romania.
Phone: 0040771754596; Fax: 0040211820; E-mail: doravre@ yahoo.com 
optimizarea tehnicii MAS-PCR (Multiplex Allele-Specific Polymerase Chain Reaction) pentru detecția mutațiilor genei rpoB şi precizarea tipului şi frecvenței acestor mutații. Material şi metodă: Am testat 47 de tulpini nonduplicat, MDR-TB, incluzând şi tulpini XDR-TB (tuberculoza cu rezistență extinsă), izolate în perioada $2007-$ 2012, folosind tehnica MAS-PCR pentru depistarea mutațiilor în codonii 531, 526 şi 516 ai genei rpoB. Rezultate: Cea mai frecventă mutație a fost localizată la nivelul codonului 531 (63,82\%), în timp ce doar 12,76\% dintre tulpini au prezentat mutație în codonul 516, iar 10,63\% dintre tulpini au avut mutație în codonul 526; la şase tulpini nu am identificat mutații în codonii țintiți. Concluzie: Tehnica MAS-PCR a permis evidențierea mutațiilor predominante în zona noastră, cu o bună sensibilitate $(87,2 \%)$, ceea ce sugerează utilitatea acestui test în diagnosticul rapid al MDR-TB.

Cuvinte cheie: $M D R-T B, M A S-P C R$, rezistența la RIF, gena rpoB

Received: $5^{\text {th }}$ April 2013; Accepted: $31^{\text {st }}$ August 2013; Published: $9^{\text {th }}$ September 2013.

\section{Introduction}

Tuberculosis (TB) represents a major global public health issue (1), with an estimated 8.7 million new cases in 2011 (2). The emergence of drug-resistant strains, due to genomic mutations in specific genes, poses a great concern for the management of this disease and the success of control programs $(3,4)$. Resistance to at least rifampicin (RIF) and isoniazid (INH) defines multidrug-resistant tuberculosis (MDRTB) (5). MDR-TB with additional resistance to fluoroquinolones and to at least one of three injectable drugs: capreomycin, kanamycin, or amikacin characterizes extensively drug-resistant tuberculosis (XDR-TB) (6). MDR-TB strains are spreading worldwide, reaching epidemic proportions in many countries, such as India, China and Russian Federation $(2,5)$. A 2012 World Health Organization (WHO) report estimates that $3.7 \%$ of new cases and $20 \%$ of previously treated cases are MDR-TB (2). Romania has one of the highest incidences of TB in Europe and is the first in the European Union in terms of tuberculosis incidence rate (101 cases/100.000 population in 2011) and mortality rate (6 cases/100.000 population in 2011) (2). The number of estimated cases of MDR-TB situated us among the first places in European countries in 2011(2).

Since the risk of developing resistance to both INH and RIF under optimal treatment conditions is very small, with an estimated mu- tation rate of approximately $10^{-14}$, it is considered that multidrug resistance appears mostly when treatment is not optimal (3).

Conventional drug susceptibility testing is time-consuming, costly and raises technical problems due to difficulties to control the inoculum size and the stability of the compounds in different culture media. Slow diagnosis and insufficient testing for MDR-TB contribute to its dissemination (3). New molecular biology techniques are being introduced for rapid diagnosis and for detection of multi-resistant strains. This is possible due to a better understanding of molecular mechanisms responsible for drug resistance in those strains (7).

Resistance to RIF can be used as a marker for MDR-TB, because it is usually preceded by that to INH, isolated resistance to RIF being extremely rare $(5,8)$. In approximately $98 \%$ of cases, RIF resistance is caused by mutations in the rpoB gene encoding the RNA polymerase-subunit $(3-5,9)$. Most mutations occur in the short 81-bp region in rpoB gene (codons 507 to 533$)(4,9,10)$, and according to Mokrousov et al., up to $95 \%$ of RIF-resistant strains have mutations in codons 531, 526 and 516 (5).

The objectives of our study were to optimize a multiplex allele-specific PCR technique (MAS-PCR) to detect rpoB mutations in the three codons responsible for the majority of RIF-resistant strains (codons 531, 526 and 516) and to specify the frequency of these mutations. 


\section{Material and methods}

\section{Selected strains}

We have tested 47 non-duplicate MDRTB and XDR-TB strains, from sputum of patients admitted to the Clinical Hospital of Pulmonology Iaşi, Romania, during 2007-2012. This is a 347-bed hospital serving the north-east region of Romania, with a population of around 4.5 million inhabitants.

\section{Drug susceptibility testing (DST)}

The strains were tested for antibiotic susceptibility using a reference standard absolute concentration method and proportion method (11 - 13). M. tuberculosis H37Rv was used as control. DST was performed for first and second-line antibiotics.

\section{DNA extraction procedure}

DNA extracts were obtained using a method previously described by Cavasoglu et al. (14), modified as follows: a suspension of M. tuberculosis was prepared in $300 \mu \mathrm{L}$ of sterile distilled water and adjusted to the density of a $2 \mathrm{Mc}$ Farland standard. The suspension was placed in a boiling water bath for 20 min to destroy any viable mycobacteria, followed by sonication for $15 \mathrm{~min}$. It was then centrifuged for $5 \mathrm{~min}$ at $14000 \mathrm{rpm}$ and the resulting supernatant was subjected to spectrophotometric quantification of extracted DNA.

\section{MAS-PCR}

To optimize the technique, we carried out three independent allele-specific PCR assays for detection of mutations in $r p o \mathrm{~B}$ codons 531, 526 and 516, using the Corbett Palm-Cycler (Qiagen, SUA) and primers synthesized by Eurogentec (Eurogentec S.A., Liège, Belgium). Each PCR mixture had a final volume of $20 \mu \mathrm{l}$ and contained $10 \mu \mathrm{l}$ of $1 \times$ ImmoMix ${ }^{\mathrm{TM}}$ Red Master Mix (Bioline GmbH, Germany) and $0.5 \mu \mathrm{l}$ of template DNA. We used the primer sequences and concentrations, as well as amplification conditions according to Mokrousov et al. (5). The following adjustments were made to the reactions used for detection of 531 and 526 mutations: the annealing temperature was de- creased from $70^{\circ} \mathrm{C}$ (as reported by Mokrousov et al.) to $63{ }^{\circ} \mathrm{C}$, in order to obtain amplification of the $249 \mathrm{bp}$ internal control (corresponding to rpoB region). Reference strain $M$. tuberculosis H37Rv (a wild-type strain sensitive to RIF) was included as control for amplification. Each reaction was performed in triplicate, to ensure reproducibility of results.

Detection of amplification products was done by electrophoresis in $1.5 \%$ standard agarose gels, at $130 \mathrm{~V}$ for $60 \mathrm{~min}$ and visualized under UV light using $G$ : $B O X ®$ gel imaging system (SYNGENE, Synoptics Ltd, UK).

\section{Results}

According to results of DTS, 16 strains were MDR, 8 were XDR and 23 strains were MDR with additional resistance to second-line anti-TB antibiotics (Table 1).

The presence of mutations in rpoB531/526/516 was recognized by the absence of amplification of wild-type allele-specific fragments (167 or 181 or $214 \mathrm{bp}$, respectively) due to primer-template mismatch which prevents polymerase to extend the primer.

Of the 47 tested strains, thirty $(63.82 \%)$ had mutation in codon 531, while six strains $(12.76 \%)$ presented mutation in codon 516; five strains $(10.63 \%)$ had mutation in codon 526. Six MDR strains showed no mutation in the three codons investigated, suggesting other mutation sites within $r p o B$ gene. None of the tested strains had simultaneous mutation in more than one of the targeted codons.

Combined genotyping testing for the three most common mutations in hotspot codons was able to detect $87.23 \%$ of MDR-TB strains classified by phenotypic methods.

\section{Discussion}

Tuberculosis is an important infectious disease, causing morbidity worldwide, and is included in the top three leading causes of death 
Table 1. Antibiotic resistance patterns of M. tuberculosis strains included in this study

\begin{tabular}{|c|c|c|c|}
\hline Type & Resistance pattern & No. of strains & Total \\
\hline MDR & $\begin{array}{l}\text { HIN RIF } \\
\text { HIN RIF EMB } \\
\text { HIN RIF SM }^{\mathrm{a}} \\
\text { HIN RIF EMB SM }\end{array}$ & $\begin{array}{l}5 \\
2 \\
3 \\
6\end{array}$ & 16 \\
\hline XDR & $\begin{array}{l}\text { HIN RIF EMB OFX } \text { KAN }^{\mathrm{d}} \text { DCS }^{\mathrm{e}} \\
\text { HIN RIF EMB SM OFX KAN } \\
\text { HIN RIF EMB SM OFX KAN CAP } \\
\text { HIN RIF EMB SM OFX KAN DCS } \\
\text { HIN RIF EMB SM OFX KAN PAS } \\
\text { HIN RIF EMB SM OFX KAN ETH }{ }^{\mathrm{h}} \text { CAP }\end{array}$ & $\begin{array}{l}1 \\
1 \\
1 \\
1 \\
1 \\
3\end{array}$ & 8 \\
\hline $\begin{array}{l}\text { MDR with additional } \\
\text { resistance to second-line } \\
\text { anti-TB antibiotics }\end{array}$ & $\begin{array}{l}\text { HIN RIF EMB OFX } \\
\text { HIN RIF EMB DCS } \\
\text { HIN RIF EMB OFX ETH } \\
\text { HIN RIF EMB OFX ETH DCS } \\
\text { HIN RIF EMB SM KAN } \\
\text { HIN RIF EMB SM ETH } \\
\text { HIN RIF EMB SM KAN CAP } \\
\text { HIN RIF EMB SM KAN ETH } \\
\text { HIN RIF SM KAN CAP } \\
\text { HIN RIF SM KAN } \\
\text { HIN RIF SM ETH }\end{array}$ & $\begin{array}{l}4 \\
1 \\
1 \\
1 \\
3 \\
2 \\
5 \\
3 \\
1 \\
1 \\
1\end{array}$ & 23 \\
\hline
\end{tabular}

a ethambutol; ${ }^{\mathrm{b}}$ streptomycin; ${ }^{\mathrm{c}}$ ofloxacin; ${ }^{\mathrm{d}}$ kanamycin; ${ }^{\mathrm{e}} \mathrm{D}$-cycloserine; ${ }^{\mathrm{f}}$ capreomycin; ${ }^{\mathrm{g}}$ para-aminosalicylic acid; ${ }^{\mathrm{h}}$ ethionamide.

from a single infectious agent (together with malaria and HIV) (15). In Eastern Europe and central Asia, levels of MDR-TB remain high, reaching $32 \%$ of new cases and over $50 \%$ of previously treated cases in 2011 (2).

Despite progress of surveillance, according to WHO Global Tuberculosis Report 2012, at global level, the rate of notified MDR-TB cases remains low (19\%) (2). In Romania, out of the 850 estimated cases in 2011, only 485 cases were confirmed as a result of insufficient testing for MDR-TB (38\% of newly diagnosed TB cases and $42 \%$ of those previously treated) (2).

Currently, diagnosis of MDR-TB is influenced by prolonged time required to obtain results, causing delay in initiating appropriate treatment, extension of hospitalization and therapy, with increased incidence of side effects and a high risk of dissemination of resistant strains in population. Ac- cording to the Romanian National Tuberculosis Control Program, the average cost of individualized treatment for MDR-TB is up to 200 times higher than for chemosensitive tuberculosis, depending on the regimen and duration (16).

Molecular diagnostic techniques (MDT) can detect mutations responsible for drug resistance before phenotypic results, having an immediate impact on patient management. Unlike susceptibility testing that evaluates the phenotype expressed in artificial laboratory conditions, MDT permit analysis of the genotype found in clinical samples and associated with patient's disease. Also, the risk of contamination when using MDT is lower than for phenotypic tests. However, MDT have a number of disadvantages: multiple tests are needed to highlight the various mutations; some techniques (e.g. PCR) reveal only previously known mutations, so the absence of detection 
doesn't necessarily mean the absence of resistance; not all mutations have a clinical expression; difficulties in detection of resistant mutants in mixed drug-resistant and -susceptible infections (3). Despite these disadvantages, molecular techniques represent valuable adjuncts to conventional phenotypic tests in screening of drug-resistance (3).

The present study focused on the use of MAS-PCR as a potential screening method for MDR-TB in our country. By this technique, detection of mutations in the three codons of 81-bp region of the $\mathrm{rpoB}$ gene correlated $87.23 \%$ with phenotypic RIF resistance. Previous studies on samples from different Russian settings showed a correlation of 86.1 to $100 \%$ between genotypic detection of mutations in rpoB531/526/516 and phenotypic testing (5, 17-20). Furthermore, Mokrousov et al. suggested that analysis of other $r p o B$ hot spot codons in Russian region is insignificant for prediction of RIF resistance (5). Studies using other molecular techniques, such as Genotype MTBDRplus assay, identified $95.4 \%$ to 99\% of RIF-resistant strains in China and South Africa, respectively $(21,22)$. These regional differences could be explained by variations in relative frequencies of investigated mutations (5). A previous study, performed in Romania by Hirstea et al., described a Real Time PCR technique for MDR-TB identification and revealed a good sensitivity $(92 \%)$ but a poor specificity $(74 \%)$ of this test for detection of RIF resistance and offered no data regarding the types and frequencies of mutations among tested strains (23).

The most frequent mutation found among our clinical specimens was located at codon $531(63.82 \%)$. This is in accordance with reports from other regions, such as China and South Africa (63.2\% and $70.5 \%$, respectively) $(21,22)$ and some European countries: Turkey $56.1 \%$, Italy $-60.4 \%$, Bulgaria - $65 \%$, Ukraine $73 \%$, Germany $-75.7 \%$ (10, 24 - 27). However, our study showed great differences from our neighboring countries, Hungary with a lower frequency (31\%) and Republic of Moldova with a higher frequency $(86.8 \%)(28,29)$.
Mutation in codon 516 occurred at a rate of $12.76 \%$, higher than in neighboring countries: Republic of Moldova (4.4\%) and Ukraine $(8 \%)$, but much smaller than in Hungary $(37.9 \%)(29,26,28)$. Other studies show that this mutation occurs with frequencies varying greatly from $2 \%$ in China and $2.9 \%$ in Germany (representing the rarest mutation among the three) to $9.6 \%$ in South Africa $(21,22,27)$.

The less common mutation was found in codon $526(10.63 \%)$. However, this percentage is greater than those reported in Republic of Moldova $(0.9 \%)$ and Hungary $(6.9 \%)(29,28)$. Other studies also mention low frequencies for this type of mutation in countries like: Italy (6.5\%), South Africa (8.6\%), China (10\%), Ukraine (12.5\%), Germany (13.6\%) and Turkey $(17.1 \%)(10,21,22,24,26,27)$.

The mutation profile among strains circulating in north-east of Romania resembles that found in Ukraine, other European countries and even more distant regions with high MDR-TB incidence, like China and South Africa; interestingly, there were fewer similarities with two of the neighboring countries: Hungary and Republic of Moldova.

Another research conducted at the Swedish Institute for Communicable Disease Control by Rosales-Klintz et al., on a strain collection which included also 20 isolates from central Romania (Hospital of Pulmonology, Braşov), showed a frequency of $r p o B$ mutations of $85 \%$, with the most common mutation being in codon 526 (12 strains from 17 RIF-resistant isolates). Contradictory with our findings, mutations in codon 531 were very rare (only 2 of 17 strains) (30). These discordant results can be caused by differences among Romanian regions and emphasize the need to include and test other strains from various parts of the country.

\section{Conclusions}

High prevalence of tuberculosis in our country and the emerging risk of MDR-TB impose continuous surveillance of antibiotic resis- 
tance and development of methods for rapid detection of multi-resistant strains.

The technique used by us allowed the detection of most MDR strains (87.2\%) circulating in our region, by identifying the prevalent mutations which appear in codons $531(63.8 \%)$, $516(12.7 \%)$ and $526(10.6 \%)$. Thus, MAS-PCR could represent a useful diagnostic tool, offering the advantage of rapidity and the possibility for optimization of antibiotic therapy. Since not all strains showed mutations in the three codons, further studies are required in order to explain all phenotypic resistance profiles.

This is the first study conducted in Romania on MAS-PCR for detection of the $r p o B$ mutation type predominant in our region, showing a high frequency of RIF resistance caused by mutations in codon 531 .

\section{Disclosure of Conflict of Interests}

The authors declare that they have no conflict of interest.

\section{Acknowledgements}

The study has been carried out at: "Grigore T. Popa" University of Medicine and Pharmacy Iaşi, Microbiology Department, 16, Universității Street, Iaşi 700115, Romania.

\author{
Abbreviations \\ bp - base pairs \\ CAP - capreomycin \\ DCS - D-cycloserine \\ DST - drug susceptibility testing \\ EMB - ethambutol \\ ETH - ethionamide \\ INH - isoniazid \\ KAN - kanamycin \\ MAS-PCR - multiplex allele-specific polymerase \\ chain reaction \\ MDR-TB - multidrug-resistant tuberculosis \\ MDT - molecular diagnostic techniques \\ OFX - ofloxacin \\ PAS - para-aminosalicylic acid
}

RIF - rifampicin

SM - streptomycin

TB - tuberculosis

XDR-TB - extensively drug-resistant tuberculosis WHO - World Health Organization

\section{References}

1. Gupta R, Espinal MA, Raviglione MC. Tuberculosis as a major global health problem in the 21 st century: a WHO perspective. Semin Respir Crit Care Med. 2004;25(3):245-53.

2. WHO: Global tuberculosis report 2012. http://www.who.int/tb/data.

3. Victor TC, van Helden PD, Warren R. Prediction of drug resistance in M. tuberculosis: molecular mechanisms, tools, and applications. IUBMB Life. 2002;53(4-5):231-7.

4. Ramaswamy S, Musser JM. Molecular genetic basis of antimicrobial agent resistance in Mycobacterium tuberculosis: 1998 update. Tuber Lung Dis. 1998;79(1):3-29.

5. Mokrousov I, Otten T, Vyshnevskiy B, Narvskaya O. Allele-specific rpoB PCR assays for detection of rifampinresistant Mycobacterium tuberculosis in sputum smears. Antimicrob Agents Chemother. 2003;47(7):2231-5.

6. Parsons LM, Somoskövi A, Gutierrez C, Lee E, Paramasivan $\mathrm{CN}$, Abimiku A et al. Laboratory diagnosis of tuberculosis in resource-poor countries: challenges and opportunities. J Clin Microbiol Rev. 2011;24(2):314-50.

7. Palomino JC. Molecular detection, identification and drug resistance detection in Mycobacterium tuberculosis. FEMS Immunol Med Microbiol. 2009;56(2):103-11.

8. Gillespie SH. Evolution of Drug Resistance in Mycobacterium tuberculosis: Clinical and Molecular Perspective. Antimicrob Agents Chemother. 2002; 46(2): 267-74.

9. Telenti A, Imboden P, Marchesi F, Lowrie D, Cole S, Colston MJ et al. Detection of rifampicin-resistance mutations in Mycobacterium tuberculosis. Lancet. 1993;341(8846):647-50.

10. Cavusoglu C, Hilmioglu S, Guneri S, Bilgic A. Characterization of rpoB mutations in rifampin-resistant clinical isolates of Mycobacterium tuberculosis from Turkey by DNA sequencing and line probe assay. J Clin Microbiol. 2002;40(12):4435-8.

11. G. Canetti, S. Froman, J. Grosset, P. Hauduroy. Mycobacteria: Laboratory methods for testing drug sensitivity and resistance. Bull World Health Organ. 1963;29:565-8.

12. G. Canetti, W. Fox, A. Khomenko, H.T. Mahler, N.K. Menon, D.A. Mitchison et al. Advances in techniques of testing mycobacterial drug sensitivity, and the use of sensitivity tests in tuberculosis control programmes. Bull World Health Organ. 1969;41:21-43.

13. Kim SJ. Drug-susceptibility testing in tuberculosis: Methods and reliability of results. Eur Respir J. 2005;25:564-9.

14. Cavusoglu C, Turhan A, Akinci P, Soyler I. Evalua- 
tion of the Genotype MTBDR assay for rapid detection of rifampin and isoniazid resistance in Mycobacterium tuberculosis isolates. J Clin Microbiol. 2006;44(7):2338-42.

15. Vitoria M, Granich R, Gilks CF, Gunneberg C, Hosseini M, Were $\mathrm{W}$ et al. The Global Fight Against HIV/AIDS, Tuberculosis, and Malaria Current Status and Future Perspectives. Am J Clin Pathol.2009;131:844-8.

16. Ghid Metodologic De Implementare A Programului Național De Control Al Tuberculozei 2007-2011, Institutul Naţional De Pneumologie "Marius Nasta" Bucureşti, 2007, http://www.srp.ro/Programul-Nationalde-Control-al-Tuberculozei-118.htm

17. Mokrousov I, Filliol I, Legrand E, Sola C, Otten T, Vyshnevskaya E et al. Molecular characterization of multiple-drug-resistant Mycobacterium tuberculosis isolates from northwestern Russia and analysis of rifampin resistance using RNA/RNA mismatch analysis as compared to the line probe assay and sequencing of the rpoB gene. Res Microbiol. 2002;153(4):213-9.

18. Generozov EV, Akopian TA, Govorun VM, Chernousova LN, Larionova EE, Savinkova SN et al. Molecular characteristics of multiresistant clinical strains of Mycobacterium tuberculosis isolated in Russia. Mol Gen Mikrobiol Virusol. 2000;(1):11-7. Russian

19. Nikolayevsky V, Brown T, Balabanova Y, Ruddy M, Fedorin I, Drobniewski F. Detection of mutations associated with isoniazid and rifampin resistance in Mycobacterium tuberculosis isolates from Samara Region, Russian Federation. J Clin Microbiol. 2004;42(10):4498-502.

20. Toungoussova OS, Sandven P, Mariandyshev AO, Nizovtseva NI, Bjune G, Caugant DA. Spread of drug-resistant Mycobacterium tuberculosis strains of the Beijing genotype in the Archangel Oblast, Russia. J Clin Microbiol. 2002;40(6): 1930-7.

21. Huang WL, Chen HY, Kuo YM, Jou R. Performance assessment of the GenoType MTBDRplus test and DNA sequencing in detection of multidrug-resistant Mycobacterium tuberculosis. J Clin Microbiol. 2009;47(8):2520-4.

22. Barnard M, Albert H, Coetzee G, O'Brien R, Bosman ME. Rapid molecular screening for multidrug-resistant tuberculosis in a high-volume public health laboratory in
South Africa. Am J Respir Crit Care Med. 2008; 177(7):787-92.

23. Hristea A, Otelea D, Paraschiv S, Macri A, Baicus C, Moldovan $\mathrm{O}$ et al. Detection of Mycobacterium tuberculosis resistance mutations to rifampin and isoniazid by realtime PCR. Indian J Med Microbiol. 2010;28:211-6.

24. Miotto P, Piana F, Penati V, Canducci F, Migliori GB, Cirillo DM. Use of genotype MTBDR assay for molecular detection of rifampin and isoniazid resistance in Mycobacterium tuberculosis clinical strains isolated in Italy. J Clin Microbiol. 2006;44(7):2485-91.

25. Valcheva V, Mokrousov I, Narvskaya O, Rastogi N, Markova N. Molecular snapshot of drug-resistant and drug-susceptible Mycobacterium tuberculosis strains circulating in Bulgaria. Infect Genet Evol. 2008;8:657-63.

26. Dymova MA, Liashenko OO, Poteiko PI, Krutko VS, Khrapov EA, Filipenko ML. Genetic variation of Mycobacterium tuberculosis circulating in Kharkiv Oblast, Ukraine. BMC Infect Dis. 2011;11:77.

27. Hillemann D, Weizenegger M, Kubica T, Richter E, Niemann S. Use of the genotype MTBDR assay for rapid detection of rifampin and isoniazid resistance in Mycobacterium tuberculosis complex isolates. J Clin Microbiol. 2005;43(8):3699-703.

28. Bártfai Z, Somoskövi A, Ködmön C, Szabó N, Puskás E, Kosztolányi L et al. Molecular characterization of rifampin-resistant isolates of Mycobacterium tuberculosis from Hungary by DNA sequencing and the line probe assay. J Clin Microbiol. 2001;39(10):3736-9.

29. Crudu V, Stratan E, Romancenco E, Allerheiligen V, Hillemann A, Moraru N. First evaluation of an improved assay for molecular genetic detection of tuberculosis as well as rifampin and isoniazid resistances. J Clin Microbiol. 2012;50(4):1264-9.

30. Rosales-Klintz S, Jureen P, Zalutskayae A, Skrahina A, Xu B, Yi Hu Y et al. Drug resistance-related mutations in multidrug-resistant Mycobacterium tuberculosis isolates from diverse geographical regions. Int $\mathbf{J}$ Mycobacteriol. 2012;1(3):124-30. 